\title{
DEVELOPING THE LEARNING MATERIALS OF READING 2 INTEGRATED WITH ISLAMIC VALUES
}

\author{
Amirudin Latif \\ amirpubian@gmail.com \\ Muhammadiyah University of Metro
}

\begin{abstract}
The objective of the study is to develop the learning materials of reading 2 integrated with Islamic values. The design of the study is research and development (R\&D). The setting of the study is English Education Department of Teacher Training and Education Faculty of Muhammadiyah University of Metro. The respondents of study are lecturer and students of the third semester. The steps of the study are need analysis, the result of need analysis, material development, expert validation, try out, and final product. The result of the study is materials of reading 2 inserted with Islamic values. The materials are compiled in a book which consists of five units. Each unit consists of text material, example of texts, vocabulary, and exercises.
\end{abstract}

Keywords: material, reading 2, and Islamic values

\section{INRODUCTION}

Learning materials have an important role in English Language Teaching (ELT) because they are the key components in the language program (Richard, 2001, p. 251). The materials provide the foundation of the lesson, the balance of skills, and language exercises. Therefore, almost all teachers or lecturers use learning materials as a primary source of teaching. In addition, for students, the learning material is the main source to achieve the learning objectives.

Cunningsworth $(1995$, p. 7) summarizes the role of the learning materials in the language learning (especially course books) namely a) the source of presenting the lesson, b) sources of activities for the students in the language rehearsal and interactive communication, c) the reference source for students in grammar, vocabulary, etc, d) the stimulating sources and ideas for class activities, e) syllabus which teachers reflect on the learning objectives that have been set, f) media for teachers who are inexperienced and lack of confidence.

Furthermore Rowntree (1997, p. 92) cited by Purnama (2010) states that the materials should (a) create the students' interest, (b) remind them to learn soon, (c) tell them what they 
will learn next, (d) describe the contents of new teaching, (e) link the idea of the learners' prior learning, (f) tell the students to think about new material, (g) help the students to obtain feedback in learning, (h) encourage them to practice, (i) allow them to check on the progress that has been achieved, (j) give estimation what to do, and (k) to help the students to be better.

Reading 2 is one of the subjects in English Education Department of Muhammadiyah Universitas of Metro. Reading 2 materials development must be matched with the vision and mission of the university namely the integration of values of Al-Islam and Kemuhammadiyahan in all subjects, the curriculum of department, the students' and lecturers' need. The purpose of integrating Al-Islam and Kemuhammadiyahan on each course is that every graduate of UM Metro is not only proficient in the field of science they learn but also have a solid aqidah which will be a provision for their lives in the world and the hereafter.

Reading 2 course currently done is assisted with the learning materials. However, the learning materials of Reading 2 currently used in the reading class has not been integrated with Al-Islam and Kemuhammadiyahan. The learning materials only contain reading texts without Islamic values, and they do not characterize the vision and mission of university as well as English Education Department. Thus, to have the learning materials of Reading 2 which meet the institutional vision and mission, it is important to develop the learning materials of Reading 2 integrated with Islamic values.

\section{METHOD}

The objective of the study is intended to develop the learning material of Reading 2 used in the reading class at English Department of Teacher Training University of Muham and Education Faculty (FKIP) Muhammadiyah University of Metro. Therefore, the study uses research and development model singer proposed by Borg and Gall (1983). According to Borg and Gall there are ten steps to conduct research and development namely 1) research and information collecting (2) planning (3) develop preliminary form of product (4) preliminary field testing (5) main product revision (6) main filed testing (7) operational product revision (8) operational field testing (9) final product revision (10) dissemination and distribution.

Furthermore, the Borg and Gall's model is adapted and combined with the model of the learning materials development proposed by Tomlinson and Masuhara (2004). Thus, the study of 
developing the learning materials of Reading 2 goes through several steps namely 1) need analysis, 2) preparation of Reading 2 materials development, 2) Reading 2 materials development, 3) expert validation, 4) revision based on experts, 5) limited try out, 6) revision based on the try out, 7) final product.

Need analysis is done to find information needed prior to Reading 2 materials development. First, The existing learning materials of Reading 2 are evaluated to measure the quality of these materials in terms of the applicability and suitability for the reading class at English Department of FKIP Muhammadiyah University of Metro. This activity is done using a checklist. Then, the lecturers of Reading 2 are interviewed to get information needed for their reading class. Next, the students are also asked to tell their preference in relation to the inclusion of texts for the learning materials of Reading 2 in order that they are interested in joining the reading class. Thus, need analysis is required to obtain the preliminary data before developing Reading 2 materials.

The preparation of Reading 2 materials development is done by collecting and selecting texts. The texts can be found from various books as well as internet. The texts can be description of Islamic symbol, Islamic stories, Islamic news, and Islamic worship procedures. The texts which are obtained from many sources are simplified the language to meet the suitability for the reading class.

The developing of Reading 2 materials is done by reviewing all of the texts which are picked from several sources, simplifying the language of the text, grouping the texts based on the types of texts, compiling the texts, and completing the texts with tasks and test.

After the process of Reading 2 materials development is done, the draft is submitted to two reviewers. One reviewer is a lecturer of reading course who reviews the reading texts, and another is a lecturer of Islamic course who reviews Islamic values inserted into Reading 2 material.

After having feedback from both reviewers, the draft of Reading 2 materials is revised in terms of the types of texts, tasks, learning activities, test, and Islamic values inserted in the materials. The revision is done based on the suggestion from both reviewers. After being revised the draft is submitted to the both reviewers again to get their update feedback.

Try out is done after the draft is validated by the reviewers. The draft is given to both the students and a lecturer. The lecturer is asked to do simulation using the draft in his reading class. 
After simulation is done, both the students and lecturer are requested to fill questionnaire about the text and task readability, the text and task quality, the text and task applicability, and the test quality on the learning materials of Reading 2. After giving questionnaire to both the students and lecturer, especially the lecturer is requested to give comment on the draft.

The final product of the research and development is the learning materials of Reading 2 integrated with Islamic values. The learning materials are used in the reading class especially at the third semester of English Department. The students are facilitated with the learning materials which become their close friend during the classroom learning.

\section{RESULT}

Before developing Reading 2 materials integrated with Al-Islam and Kemuhammadiyahan, the already existing Reading 2 material is reviewed to find the strength and weakness. It turns out that the currently used Reading 2 materials do not contain the values of Al-Islam and Kemuhammadiyahan. The content of the existing reading material it still general, so it needs to accommodate the values of Al-Islam and Kemuhammadiyahan into the material to fit with the vision and mission of the University of Muhammadiyah Metro.

Need analysis is done by conducting interview with the lecturer and students to get the data in terms of the kinds of texts, tasks, and test as well as Islamic values which can be inserted to reading material.

Interviews showed that Reading 2 materials which need to be developed are five types of text namely descriptive text, recount text, narrative text, report text, and procedure text. Meanwhile the Islamic values that needs to be inserted consist of a description of places of worship such as mosques, descriptions of people like Antichrist, a description of the unseen things like heaven and hell. Besides Islamic values which need to be inserted in the form of specific experience in conducting worship in a certain time. Furthermore, the Islamic values can also be inserted through the stories such exemplary stories of the prophets and messenger, companion stories, and the stories of people - pious people and ungodly ones. Then, the values could be inserted in the form of knowledge such as information about the angels, jinn, and others. Finally, Islamic values and Kemuhammadiyahan through the reading containing the 
procedures of doing worship in accordance to Tarjih muhammadiyah such as ablutions, tayamum, prayer, fasting, Hajj and Umrah.

After doing need analysis forReading 2 material, then researchers began developing reading 2 materials by adopting and adepting Islamic text from various sources, making texts, and completing the texts with exercises in the form of questions to test the comprehension. Reading 2 material in this research consists of 5 units: descriptive, recount, narrative, report, and procedures.

Unit I descriptive text is developed starting from the definition, generic structure, language features, and the examples of descriptive text completed with exercises in the form of questions. Topics in descriptive text are Sheikh Zayed Mosque, Faisal Mosque, Badshahi Mosque, Hassan II Mosque, Taj-lul-mosque, the Istiqlal Mosque, Imam Reza Shrine Mosque, Al-Masjid Al-Nabawi, Masjid Al-Haram, the Antichrist, Ajwa Dates The Kaaba, Holy Quran, Hell and Jannah.

Unit II Recount text was developed from the definition, generic structure, language features, and the examples of recount completed with exercises in the form of questions. Topics in recount text are My Experience in the Eid Last Year, Pilgrimige to Mecca, and My Ramadan Experience.

Unit III Narrative text was developed from the definition, generic structure, language features, and the examples of narrative text completed with exercises in the form of questions. Topics in narrative text are Prophet Adam, Prophet Noah, Prophet Salih, Prophet Hud, Prophet Yunus, Prophet Lut, Prophet Shu'ayb, Cain and Abel, Prophet Ayyub, The Story of Moses and Al-Khidr, Story of the Three Persons Blocked in a Cave, The Story of Alqomah, The Pious Man and the Shopkeeper, the patient Old Man, Did you Thank God for Your Eyesight, Enemy Becomes a Friend, Story of an Idolator, The Shepherd, and The Story of rose sent to the Caliph Harun Rashid.

Unit IV Report text is developed starting from the definition, generic structure, language features, and the examples of report text completed with exercises in the form of questions. Topics in report text are The Angels, Jinn.

Unit V Procedure text was developed from the definition, generic structure, language features, and the examples of procedure text that comes with exercise - exercise in the form of questions. Topics in procedure are How to Perform Wudu, How to Perform Tayyamum. 
The reading material which was developed then submitted to experts for the content validation.

After Reading 2 material had been developed, the material was handed over to two experts namely an expert on Reading material and one on Al-Islam and Kemuhammadiyahan to examine its contents. Experts on reading material provided feedback on the quality of text in reading materials developed; while expert on Kemuhammadiyahan and Al-Islam provided feedback on the Islamic value and Kemuhammadiyahan inserted in Reading 2 material.

To check the quality of reading texts, the researcher asked for help Mr. Fahrudin Latif, SS, M. Hum which is one of the senior lecturer of English Study Program Teacher Training and Education Faculty of the Muhammadiyah University of Metro became a validator Reading 2. To examine the quality of Islamic values and Kemuhammadiyahan in Reading 2, the researcher asked for help Mr. Ahmad Sujino, S.Pd.I, M.Pd.I to be the validator. He is a lecturer of Al-Islam and Kemuhammadiyah at the Faculty of Islamic Studies, Muhammadiyah University of Metro. In addition, he also served as Regional Chairman of Muhammadiyah Lampung. Thus the researcher appropriately chose Mr. Ahmad Sujino, S.Pd.I., M.Pd.I to be a validator who checked and gave feedback and suggestions on Islamic values and Kemuhammadiyahan inserted in Reading 2.

After the draft of Reading 2 material was submitted to the experts above, then they gave feedback as material improvement. Mr. Fahrudin Latif, S.S., Hum who is the validator on the content of Reading 2 material gave some feedback namely; (1) each text should be completed with a vocabulary to enable students to understand the contents of the text, (2) each text should be equipped with the questions to test understanding. The questions given should not in multiplechoice questions that are likely to cause students lazy to think, (3) multiple-choice questions in the draft should be replaced with essay questions more challenging to dig up information about what, who, when, where, why, and how, (4) specially descriptive texts should be accompanied with pictures to make it easier to understand the description, (5) reading materials should not be written using Times New Roman font for typeface is less appealing to the eye, so it is advisable to use the Arial Unicode MS.

Furthermore, Mr. Ahmad Sujino, S.Pd.I., M.Pd.I gave some suggestions on the Islamic values and Kemuhammadiyahan inserted in Reading 2 material; (1) should recheck the stories from the original source namely Holy Quran and the Hadith, (2) the story of prophet Musa and 
Khidr should be given in two versions of the Holy Quran and the Hadith, (3) the materials of procedure text which contain the practices of worship such as wudu, tayamum, prayer, fasting, zakat, hajj and others should be in accordance with the Quran and Hadith as well as Tarjih Muhammadiyah, (4) the draft of Reading 2 materials is currently no literature on biography of leaders of Muhammadiyah, the biography is intended to give an introduction to the students about the leaders of Muhammadiyah.

After getting feedback from both validators, eventually researcher revise Reading 2 material that has been developed. First of all the researcher revised Reading 2 material based on the feedback from the first validator Mr. Fahrudin Latif, S.S., M.Hum about the content of reading material 2. Based on the feedback given by the validator, the researcher revised Reading 2 material with the points namely (1) completing each reading text with vocabulary, (2) replacing the multiple-choice questions with essay questions, (3) completing reading text with images primarily on descriptive text, (4) changing the type of font Times New Roman to Arial Unicode MS.

Furthermore, the researcher revised Reading 2 Material based on feedback from the validator II Mr. Ahmad Sujino, S.Pd.I., M.Pd.I about Islamic values and Kemuhammadiyahan inserted in Reading 2 material. Based on the suggestions given, researchers revised the Islamic values and Kemuhammadiyahan with the points namely; (1) completing the story with a good source of the Quran and Hadith, (2) giving the story of Moses and Khidr in the two versions of the Quran and Hadith, (3) procedure text containing religious practices that ordinances be adjusted with Tarjih Muhammadiyah , (4) adding the Reading 2 material with biographical Muhammadiyah figures.

After having finished revising Reading 2 material based on the feedback from both validators, then the researcher handed back the second draft of Reading 2 to both validators to examine the contents. After checking the Reading 2 material, finally both validators validate Reading 2 material.

After getting validation from two experts, the Reading 2 material was then applied in the teaching process . A lecturer and several students were asked to use the material of Reading 2 that has been validated by the validators. After using these materials in learning, they were given questionnaires to determine whether the Reading 2 material is suitable as a buddy of their learning reading or not. 
Try out of the product was held on June 12,2014 , starting at 08:00 to 10:00 am. At the end of the try out, researcher gave questionnaires to both the students and lecturer. The results of questionnaires given to the thirteen students show that: Four students states that Reading 2 material is interesting; meanwhile nine students state that the material is very interesting. Furthermore, eight students state that the material is very easy to learn; meanwhile five students stated that the material is easy to learn. Later, nine students state that the existing vocabulary the text is easy to understand; meanwhile four students state that vocabulary is in a moderate difficulty level. Lastly, ten students state that the directions in the exercise are very clear; meanwhile three students state that they are obvious.

The results of the questionnaire given to a lecturer of Reading 2 shows that the material of Reading 2 is very interesting. Besides that the purpose of each unit is in accordance with the standards of competence and basic competences. He also commented that instructions on the material are very clear and the material is in accordance with the vision and mission of English Study Program. Besides the content of Reading 2 material can help students to develop and sharpen their reading ability. Finally he states that the material of Reading 2 is very good and suitable to teach reading.

After doing try out, researcher revised Reading 2 material based on the results of the try out. Since the results of the try out indicate that the Reading 2 material has already been suitable and good to be applied to learning reading, the researcher did not revise the contents of Reading 2 material so that eventually the material became the final product.

After going through several stages of development, researcher finally produced Reading 2 material inserted with Islamic values and Kemuhammadiyah. The material is packed into a book which consists of five units with five topics, namely descriptive text, recount text, narrative text, a text report, and the procedure text. Each unit is equipped with vocabulary and exercises in the form of the essay question to test of understanding. 


\section{CONCLUSION AND SUGGESTION}

\section{Conclusion}

The study aims at developing Reading 2 material integrated with Islamic values and Kemuhammadiyahan. The study went through several steps namely needs analysis, development of Reading 2 material, expert validation and revision, try out and revisions, and the final product of Reading 2 material. All these stages have been carried out so as to produce Reading 2 material Integrated Islamic values and Kemuhammadiyahan. The materials were compiled in a book that consists of five units with the topics consisting of desctriptive text, recount text, narrative text, report text, and the procedure text. Each unit consists of text type, for example the Islamic nuanced texts, vocabulary, and exercises in the form of questions to test reading comprehension.

\section{Suggestions}

The number of adult juvenile delinquency is due to the lack of knowledge of religion they have. Knowledge of the religion meant is the knowledge which can make them fear of Allah. Responsibility in conveying religious knowledge is not only owned by the chaplain, chaplain and preacher but that responsibility belongs to all people.

The inviduals who often work in the field of education are teachers and lecturers. They always give their knowledge to students. In order that the knowledge given would be more

beneficial, then the teachers and lecturers insert Islamic values into the material being taught to students so that they are not only adept at the worldly science but also understand the science of the hereafter. 


\section{REFERENCE}

Anderson, M. \& Anderson, K. 1997. Text Type in English. South Yarra: Macmillan.

Anderson, M. \& Anderson, K.2003. Text Types in English. South Yarra: Macmillan.

Borg, W R \& Gall, Meredith D.1979. Educational Research. New York. Longman Inc.

Cunningsworth, A. (1995). Choosing Your Coursebook. Oxford: Heinemann.

Carey Lou, Carey O James. 2001. The systematic Design of Instruction. New York. Addison-Wesley Educational Publisher Inc.

Lestari, Lies Amin. 1999. Developing Writing Materials for Graduate Students of English Education Program. Unpublished Thesis. Graduate Program In English Language Education. State University Of Malang.

Nunan, D. 1991. Language Teaching Methodology: A Textbook For Teachers. New York: Prentice Hall.

Renandya A Willy, Richards, J.C. 2002. Methodology in Language Teaching An Anthology of Current Practice. Cambridge: Cambridge University Press.

Richards, J.C. 2001. Curriculum Development in Language Teaching. Cambridge: Cambridge University Press.

Tomlinson, B, \&Masuhara, H. 2004. Developing Course Materials: RELC Portofolio series II. Singapore: SEAMEO Regional Language Center. 